\title{
Serum vitamin D levels and survival of patients with colorectal cancer: Post-hoc analysis of a prospective cohort study
}

\author{
Hidetoshi Mezawa ${ }^{\dagger 1,2}$, Tsutomu Sugiura ${ }^{\dagger 1}$, Michiaki Watanabe33, Chihiro Norizoe ${ }^{1}$, Daisuke Takahashi ${ }^{1}$, \\ Akira Shimojima' ${ }^{1}$, Seryna Tamez' ${ }^{1}$, Yusuke Tsutsumi ${ }^{1}$, Katsuhiko Yanaga ${ }^{3}$ and Mitsuyoshi Urashima*1,2
}

\begin{abstract}
Background: Recently, serum 25-hydroxyvitamin D (25OHD) levels were shown to be associated with the survival of patients with colorectal cancer. However, 250HD levels were measured a median of 6 years before diagnosis or were predicted levels. In this study, we directly measured serum 25OHD levels at surgery and examined the association with survival among patients with colorectal cancer.

Methods: We started a prospective cohort study to find prognostic factors in patients with colorectal cancer from 2003 to 2008 and stored serum samples and clinical data. As part of a post-hoc analysis, serum 25OHD levels were measured by radioimmunoassay. Association between overall survival and serum $25 \mathrm{OHD}$ levels were computed using the Cox proportional hazard model adjusted for month of serum sampling as well as age at diagnosis, gender, cancer stage, residual tumor after surgery, time period of surgery, location of tumor, adjuvant chemotherapy and number of lymph nodes with metastasis at surgery. Unadjusted and adjusted hazard ratios (HR) and 95\% confidence intervals (95\% Cl) were determined.

Results: Serum 25OHD levels were measured in 257 patients. Only $3 \%$ had sufficient levels ( $30 \mathrm{ng} / \mathrm{ml}$ and greater). Based on month of blood sampling, an annual oscillation of 25OHD levels was seen, with levels being lower in spring and higher in late summer. Higher $25 \mathrm{OHD}$ levels were associated with better overall survival under multi-variate analysis ( $\mathrm{HR}, 0.91: 95 \% \mathrm{Cl}, 0.84$ to $0.99, P=0.027)$.

Conclusions: These results suggest that higher $25 \mathrm{OHD}$ levels at surgery may be associated with a better survival rate of patients with colorectal cancer.
\end{abstract}

\section{Background}

Sunlight exposure has been suggested to reduce cancer risk [1]. In addition, living at higher latitudes with lower sunlight exposure is positively associated with cancer mortality [2]. Because vitamin D is made under the skin by exposure to ultraviolet-B radiation in sunlight, low levels of serum vitamin D may contribute to a higher risk of morbidity and mortality associated with colon cancer [3]. One plausible explanation for why increased sun exposure and higher circulating levels of vitamin $D$ are associated with a decreased risk of deadly cancers is that

\footnotetext{
* Correspondence: urashima@jikei.ac.jp

1 Division of Molecular Epidemiology, Jikei University School of Medicine, Nishishimbashi, Minato-ku, Tokyo, Japan

+ Contributed equally

Full list of author information is available at the end of the article
}

epithelial cells convert the primary circulating form of vitamin $\mathrm{D}, 25$-hydroxyvitamin $\mathrm{D}$ (25OHD), to its active form, 1,25-dihydoroxyvitamin $\mathrm{D}$, inside the cells; this active form binds to vitamin $\mathrm{D}$ receptors in the nucleus to regulate a variety of genes [4]. These genes help prevent malignant transformation by keeping cellular proliferation and differentiation within normal ranges. In turn, if a cell becomes malignant, 1,25-dihydroxyvitamin D can induce apoptosis and prevent angiogenesis, thereby reducing the potential for the malignant cell to survive.

Two meta-analyses showed that vitamin D deficiency is a risk factor for the development of colorectal cancer $[5,6]$. Sporadic colon cancer has been induced by a western diet in a mouse model, and was prevented by increasing dietary calcium and vitamin D levels [7]. A pilot 
randomized, double-blind, placebo-controlled clinical trial showed that vitamin $\mathrm{D}$ reduced cell proliferation and increased BCL2-associated X protein, an apoptosis promoter, in colorectal mucosa [8-10]. High doses (1,100 IU) of vitamin D plus calcium were shown to significantly reduce cancer incidence in women [11], although low doses (400 IU) of vitamin D did not decrease the incidence of colorectal cancer [12]. Recently, Ng et al. demonstrated that higher pre-diagnosis blood 25OHD levels were associated with a significant improvement in overall survival of patients with colorectal cancer [13]. However, they only had a single measurement of plasma 25OHD levels taken a median of 6 years before diagnosis. Next, they calculated post-diagnosis $25 \mathrm{OHD}$ levels using race, geographic region, and baseline values of physical activity, body mass index, and vitamin D intake reported 1 to 4 years after colorectal cancer diagnosis according to Giovannucci's method [14]. Using these predicted 25OHD levels, they demonstrated that higher 25OHD levels after diagnosis of colorectal cancer may be associated with improved survival [15]. For a more accurate portrayal of 25OHD levels, we collected blood samples at surgery, measured 25OHD levels directly, and investigated the relationship between individual serum levels of 25OHD and overall survival in patients diagnosed with colorectal cancer, according to the vitamin D hypothesis [3].

\section{Methods}

\section{Informed consent}

This study was designed as post-hoc analysis of a prospective cohort study to find prognostic markers in the serum of patients with colorectal cancer from May 2003 to January 2008 and approved by the Ethics Committee for Biomedical Research of the Jikei Institutional Review Board, Jikei University School of Medicine, Tokyo, Japan. All patients provided written informed consent.

\section{Study Population}

Peripheral blood samples were obtained from colorectal cancer patients who underwent surgery at the Department of Surgery, Jikei University Hospital. Patients who were treated with chemotherapy and/or radiation before surgery to reduce the size of the tumor were excluded. Two hundred and fifty-seven patients were included in this study. Prognostic factors known to influence colorectal cancer mortality were extracted from the medical record, including age at surgery, tumor stage, primary tumor location, and year of diagnosis. According to the tumor-node-metastasis system of the American Joint Committee on Cancer [16], stages (I, II, III and IV) were determined based on pathologic analysis of the surgical specimens [17]. Residual tumor after surgery was classified into three categories: R0, no residual tumor; R1, microscopic residual tumor; and R2, macroscopic residual tumor [18]. Metastases to lymph nodes resected at surgery were pathologically examined and counted. All patients were periodically (every 0.5 to 2 months) examined on an outpatient basis to make sure they had not relapsed. Examinations consisted of standard tests, including colonoscopy and computed tomography. Patients were followed until July 31, 2009, or death, whichever came first. Because serum 25OHD levels were higher in the first half of the study span, the time period of surgery was divided into two groups (between May 2003 and December 2005 and between January 2006 and January 2008) and was used as one of the covariates.

\section{Samples and 250HD measures}

Pathological stages and number of lymph nodes with metastasis were determined the same day or the next day after surgery. In each case, serum samples were obtained in the peri-operative period and stored at $-80^{\circ} \mathrm{C}$ until $25 \mathrm{OHD}$ was measured. Serum 25OHD levels were measured twice by radioimmunoassay at SRL Inc. (Hachioji, Tokyo, Japan), as described previously $[19,20]$. When duplicated data differed by $5 \mathrm{ng} / \mathrm{mL}$ or more, measures were repeated, although this occurred in only 7 cases. Personnel who measured 25OHD levels were blinded to clinical information.

\section{Endpoints}

Because some patients could not obtain complete remission after surgery, death was used as the primary endpoint in all patients, and relapse was used as the secondary endpoint in patients who could obtain complete resection after surgery.

\section{Statistical analysis}

Analysis of variance and chi-square test were used to evaluate differences in patient characteristics between 25OHD levels, which were divided into quartiles (3-7 ng/ $\mathrm{mL}, 8-10 \mathrm{ng} / \mathrm{mL}, 11-15 \mathrm{ng} / \mathrm{mL}$, and $16-36 \mathrm{ng} / \mathrm{mL}$ ). Overall survival, cancer-specific survival, and disease-free survival curves were compared with the serum 25OHD levels using Cox proportional hazard models with or without multivariate analysis using age at diagnosis (years old), gender, calendar month of blood sampling, cancer stage (I, II, III, and IV), residual tumor (R0, R1, and R2), number of lymph nodes with metastasis, and time period of surgery (between May 2003 and December 2005 and between January 2006 and January 2008). Adjusted hazard ratios (HR) and 95\% confidence intervals (CI) were computed. All statistical analyses were performed using STATA 9.1 (STATA Corp., College Station, TX). $P<0.05$ was considered statistically significant.

\section{Results}

\section{Serum 250HD levels}

Serum 25OHD levels were measured in 257 patients (Fig. 1). Most patients (85\%) showed insufficient levels (less 


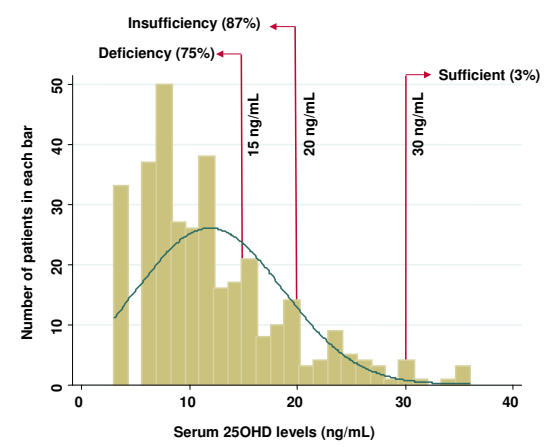

Figure 1 Histogram of serum 250HD levels.

than $20 \mathrm{ng} / \mathrm{mL}$ ) of $25 \mathrm{OHD}$; only $3 \%$ had sufficient levels (30 $\mathrm{ng} / \mathrm{ml}$ and greater). Quartile points of distribution were as follows: $25 \%, 7 \mathrm{ng} / \mathrm{mL} ; 50 \%, 10 \mathrm{ng} / \mathrm{mL}$; and $75 \%$, $15 \mathrm{ng} / \mathrm{mL}$.

Levels of 25OHD were compared based on month of blood sampling (Fig. 2). There was an annual oscillation in 25OHD levels, which were lower in spring and higher in late summer. Compared with December, 25OHD levels were significantly lower in March $(P=0.002)$ and May $(P$ $=0.001)$ and significantly higher in September $(P=$ 0.025).

Patients' characteristics according to quartiles of 25OHD levels are shown in Table 1. There were no significant differences in quartiles between age at surgery, gender, cancer stage, location of the tumor, and number of lymph nodes with metastasis. On the other hand, an earlier time period of surgery was associated with significantly higher $(P<0.001)$ 25OHD levels than a later surgical time period.

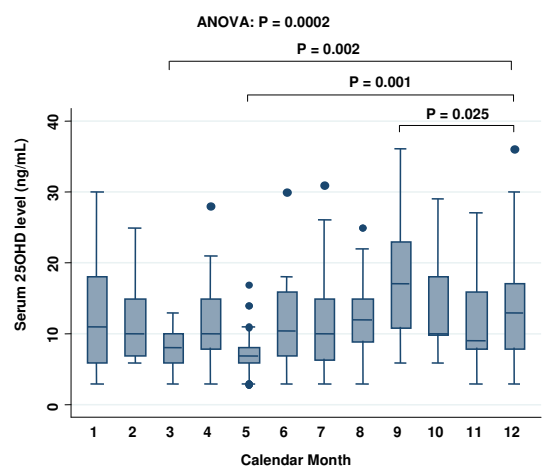

Figure 2 Serum 250HD levels in each calendar month. All points outside the range represented by circles are considered outliers.

\section{Overall survival and $250 \mathrm{HD}$}

Among 257 patients with colorectal cancer, there were 39 deaths, 30 of which were colorectal cancer-specific deaths. The median time of follow-up of participants still alive at the end of the study was 32.4 months. We assessed the influence of serum 25OHD levels on overall survival of patients using the Cox proportional hazard model adjusted for age at diagnosis (years old), gender, calendar month of blood sampling, cancer stage (I, II, III, and IV), assessment of residual tumor after surgery (R0, R1, and R2), period of surgery, and number of lymph nodes with metastasis (Table 2). Higher serum 25OHD levels were associated with a significant reduction in the risk of overall survival with adjustment for age at diagnosis, gender, calendar month of blood sampling, cancer stage, residual tumor after surgery, time period of surgery, location of tumor, adjuvant chemotherapy, and number of lymph nodes with metastasis (HR, 0.91: $95 \% \mathrm{CI}, 0.84$ to $0.99, P=0.027)$. When we divided $25 \mathrm{OHD}$ into quartiles and computed overall survival using the Cox proportional hazard model, the highest 25OHD quartile was associated with a significant reduction in death rate with adjustment for the same factors (HR, 0.16: $95 \% \mathrm{CI}, 0.04$ to $0.63, P=0.009$ ) (Table 3 ). Without adjustment, there was no association between $25 \mathrm{OHD}$ quartiles and overall survival. There was no significant association between 25OHD levels and colorectal cancer-specific death (Table 4) or disease-free survival (Table 5).

\section{Discussion}

In this study, the median serum 25OHD levels in patients with colorectal cancer was $10 \mathrm{ng} / \mathrm{mL}$, and $87 \%$ were in a vitamin D-insufficient state (less than $30 \mathrm{ng} / \mathrm{mL}$ ), which is lower than expected. SRL Inc. measured 25OHD, which has a range of $7 \mathrm{ng} / \mathrm{mL}$ to $41 \mathrm{ng} / \mathrm{mL}$ as determined by data from healthy volunteers [19]. When data from the US National Health and Nutrition Examination Survey (NHANES) 2001-2004 were compared with data from 1988-1994, the prevalence of 25OHD levels less than 10 $\mathrm{ng} / \mathrm{mL}$ increased from $2 \%$ to $6 \%$ in total and $9 \%$ to $29 \%$ in non-Hispanic blacks, with a corresponding decrease in the prevalence of levels of $30 \mathrm{ng} / \mathrm{mL}$ or more from $45 \%$ to $23 \%$ and $12 \%$ to $3 \%$, respectively [21]. The population of this study was Japanese, and the average skin color was between that of white and black subjects. The study period was between 2003 and 2008, which, although partly overlapping the later period of NHANES 20012004, was conducted mostly after that study. Moreover, populations who develop colorectal cancer tend to have lower serum $25 \mathrm{OHD}$ levels [5,6]. Thus, a higher prevalence of 25OHD insufficiency in Japanese patients with colorectal cancer after 2003 may be plausible, although we do not have exact controls to verify this hypothesis. 
Table 1: Patient characteristics according to quartile of serum $250 \mathrm{HD}(\mathbf{n}=\mathbf{2 5 7})$

\begin{tabular}{|c|c|c|c|c|c|}
\hline & $\begin{array}{l}\text { Quartile } 1 \text { (3-7 } \\
\mathrm{ng} / \mathrm{mL}) \mathrm{n}=71\end{array}$ & $\begin{array}{c}\text { Quartile } 2(8-10 \\
n g / m L) n=58\end{array}$ & $\begin{array}{c}\text { Quartile } 3(11-15 \\
n g / m L) ~ n=65\end{array}$ & $\begin{array}{c}\text { Quartile 4(16-36 } \\
n g / m L) n=63\end{array}$ & $P$ value \\
\hline $\begin{array}{l}\text { Serum } 250 H D, n g / m L, \text { mean } \\
\pm \text { SD }\end{array}$ & $5.2 \pm 1.7$ & $9.0 \pm 0.8$ & $12.6 \pm 1.4$ & $21.9 \pm 5.2$ & \\
\hline Age at surgery, years & $64 \pm 15$ & $66 \pm 13$ & $65 \pm 12$ & $65 \pm 10$ & $0.76^{* 1}$ \\
\hline Gender, \% female & 41 & 43 & 34 & 26 & $0.18^{* 2}$ \\
\hline Stage, \% & & & & & $0.78^{* 2}$ \\
\hline Stage I & 21 & 17 & 18 & 24 & \\
\hline Stage II & 23 & 31 & 37 & 22 & \\
\hline Stage III & 35 & 32 & 31 & 35 & \\
\hline Stage IV & 21 & 20 & 14 & 19 & \\
\hline Location of tumor, $\%$ & & & & & $0.24^{* 2}$ \\
\hline Proximal colon & 38 & 44 & 40 & 27 & \\
\hline Distal colon & 32 & 19 & 18 & 23 & \\
\hline Rectum & 30 & 37 & 42 & 50 & \\
\hline Type of resection, $\%$ & & & & & $0.84^{* 2}$ \\
\hline Ro & 76 & 79 & 82 & 81 & \\
\hline R1 & 9 & 10 & 8 & 4 & \\
\hline R2 & 15 & 11 & 10 & 15 & \\
\hline $\begin{array}{l}\text { Number of lymph nodes } \\
\text { with metastasis }\end{array}$ & $2.2 \pm 4.0$ & $3.0 \pm 6.8$ & $2.2 \pm 4.0$ & $1.6 \pm 3.0$ & $0.87^{* 3}$ \\
\hline Time period of surgery & & & & & $<0.001 * 2$ \\
\hline May 2003 - December 2005 & 27 & 43 & 55 & 65 & \\
\hline January 2006 - January 2008 & 73 & 57 & 45 & 35 & \\
\hline
\end{tabular}

Levels of 25OHD oscillated with the seasons, showing lower levels in spring and higher levels in late summer. This finding was similar to that reported in a British study [22]. In an ecological study, the survival of colon cancer patients in Norway was highest for those diagnosed in the summer and autumn [23]. These findings are consistent with our results.

Among 257 Japanese patients with colorectal cancer, higher 25OHD levels were associated with a significantly better overall survival under Cox proportional hazard models with multi-variate adjustment for month of serum sampling as well as age at diagnosis, gender, cancer stage, residual tumor after surgery, time period of surgery, and number of lymph nodes with metastasis at surgery, which is consistent with previous studies $[14,15]$. However, without adjustment, there was no association between 25OHD levels and overall survival. There was no significant association between 25OHD levels and colorectal cancer-specific deaths or disease-free survival. A meta-analysis showed that vitamin D supplements may improve overall survival [24] as well as cardiovascular mortality [25]. Thus, patients with higher vitamin D levels may have an advantage in both cancer- and non-cancer-related deaths, leading to an increase in overall survival rather than disease-free survival.

In patients with early-stage non-small-cell lung cancer [26] or breast cancer [27], higher 25OHD levels were reported to be associated with better prognosis. In contrast, Freedman et al. examined 536 cancer deaths in 146,578 person-years, and found an inverse relationship between 25OHD levels and colorectal cancer mortality, but not other types of cancers [28]. A positive association between serum 25OHD levels and survival may be observed in colorectal cancer, but is still controversial in other types of cancers.

This study has several limitations. Our study population was not large enough to detect minor differences in 25OHD levels. Moreover, our findings could be limited 
Table 2: Cox proportional hazard models of overall survival without or with multivariate adjustment*1

\begin{tabular}{|c|c|c|c|c|c|c|}
\hline \multirow[t]{2}{*}{ Variable } & \multicolumn{3}{|c|}{ Single-variate analyses } & \multicolumn{3}{|c|}{ Multivariate analysis } \\
\hline & Crude HR & $95 \% \mathrm{Cl}$ & $P$ value & AHR & $95 \% \mathrm{Cl}$ & $P$ value \\
\hline $250 H D, n g / m L$ & 0.98 & 0.93-1.02 & 0.31 & 0.91 & $0.84-0.99$ & 0.027 \\
\hline Age at surgery, years & 1.01 & $0.98-1.04$ & 0.49 & 1.07 & $1.03-1.12$ & 0.002 \\
\hline Gender, female & 1.26 & $0.66-2.41$ & 0.49 & 1.59 & $0.49-5.15$ & 0.44 \\
\hline \multicolumn{7}{|l|}{ Time period of surgery } \\
\hline May 2003 - December 2005 & 0.94 & $0.48-1.85$ & 0.87 & 0.41 & $0.13-1.27$ & 0.12 \\
\hline January 2006 - January 2008 & reference & & & & & \\
\hline \multicolumn{7}{|l|}{ Stage } \\
\hline Stage I & 0.00 & - & - & 0.00 & - & - \\
\hline Stage II & 0.02 & $0.01-4.32$ & $<0.001$ & 0.02 & $0.02-1.74$ & 0.13 \\
\hline Stage III & 0.13 & $0.07-0.27$ & $<0.001$ & 1.13 & $0.16-7.85$ & 0.90 \\
\hline Stage IV & Reference & & & Reference & & \\
\hline \multicolumn{7}{|l|}{ Location of tumor } \\
\hline Proximal colon & 1.07 & $0.52-2.22$ & 0.86 & 1.42 & $0.55-3.68$ & 0.47 \\
\hline Distal colon & 0.45 & $0.15-1.34$ & 0.15 & 0.42 & 0.09-1.94 & 0.27 \\
\hline Rectum & Reference & & & Reference & & \\
\hline \multicolumn{7}{|l|}{ Type of resection, \% } \\
\hline R0 & 0.04 & 0.02-0.09 & $<0.001$ & 0.01 & $0.00-0.11$ & $<0.001$ \\
\hline $\mathrm{R} 1$ & 1.04 & $0.48-2.26$ & 0.92 & 0.44 & $0.11-1.78$ & 0.25 \\
\hline $\mathrm{R} 2$ & Reference & & & Reference & & \\
\hline Adjuvant chemotherapy & 6.06 & $2.15-17.10$ & 0.001 & 0.75 & $0.17-3.34$ & 0.71 \\
\hline Number of lymph nodes with metastasis*2 & 1.08 & $1.05-1.11$ & $<0.001$ & 1.09 & $1.02-1.16$ & 0.016 \\
\hline \multicolumn{7}{|c|}{$\begin{array}{l}\text { *1: Multivariate hazard ratios (HR), 95\% confidence intervals (CI), and } P \text { values were adjusted for age at diagnosis (years), gender, calendar } \\
\text { month of blood sampling, cancer stage (I, II, III, and IV), residual tumor after surgery (R0, no residual tumor; R1, microscopic residual tumor; R2, } \\
\text { macroscopic residual tumor), time period of surgery (between May } 2003 \text { and December } 2005 \text { or between January } 2006 \text { and January } 2008) \text {, } \\
\text { location of tumor, adjuvant chemotherapy, and number of lymph nodes with metastasis. } \\
\text { *2: Lymph nodes were resected at surgery, and metastases in lymph nodes were confirmed pathologically. }\end{array}$} \\
\hline
\end{tabular}

Table 3: Cox proportional hazard models with multivariate adjustment*1

\begin{tabular}{lcc}
\hline Covariate & Hazard Ratio & P value \\
\hline 25OHD, ng/mL & & 0.22 \\
3-7 (Quartile 1) & 0.50 & 0.29 \\
8-10 (Quartile 2) & 0.55 & $0.16-1.54$ \\
$11-15$ (Quartile 3) & Reference & $0.18-1.65$ \\
$16-36$ (Quartile 4) & 0.16 & 0.009 \\
\hline
\end{tabular}

*1: Multivariate hazard ratios, $95 \%$ confidence intervals, and $P$ values were adjusted for age at diagnosis (years), gender, calendar month of blood sampling, cancer stage (I, II, III, and IV), residual tumor after surgery (R0, no residual tumor; R1, microscopic residual tumor; R2, macroscopic residual tumor), time period of surgery (between 2003 and 2005 or between 2006 and 2008), and number of lymph nodes with metastasis.

*2: Lymph nodes were resected at surgery and metastases in lymph nodes were confirmed pathologically. 
Table 4: Cox proportional hazard models of cancer death without or with multivariate adjustment*1

\begin{tabular}{|c|c|c|c|c|c|c|}
\hline \multirow[t]{2}{*}{ Variable } & \multicolumn{3}{|c|}{ Single-variate analyses } & \multicolumn{3}{|c|}{ Multivariate analysis } \\
\hline & Crude HR & $95 \% \mathrm{Cl}$ & $P$ value & AHR & $95 \% \mathrm{Cl}$ & $P$ value \\
\hline $250 H D, n g / m L$ & 0.99 & 0.94-1.05 & 0.75 & 0.98 & $0.89-1.08$ & 0.67 \\
\hline Age at surgery, years & 0.98 & $0.96-1.01$ & 0.26 & 1.02 & $0.96-1.08$ & 0.57 \\
\hline Gender, female & 1.36 & $0.65-2.85$ & 0.41 & 1.14 & $0.24-5.34$ & 0.87 \\
\hline \multicolumn{7}{|l|}{ Time period of surgery } \\
\hline May 2003 - December 2005 & 1.45 & $0.67-3.13$ & 0.87 & 1.32 & $0.28-6.19$ & 0.73 \\
\hline January 2006 - January 2008 & reference & & & & & \\
\hline \multicolumn{7}{|l|}{ Stage } \\
\hline Stage I & 0.00 & - & - & 0.00 & - & - \\
\hline Stage II & 0.00 & - & $<0.001$ & 0.00 & - & - \\
\hline Stage III & 0.01 & $0.04-0.20$ & $<0.001$ & 0.49 & $0.02-10.28$ & 0.65 \\
\hline Stage IV & Reference & & & Reference & & \\
\hline \multicolumn{7}{|l|}{ Location of tumor } \\
\hline Proximal colon & 0.77 & $0.31-1.88$ & 0.56 & 0.66 & $0.17-2.56$ & 0.54 \\
\hline Distal colon & 0.56 & $0.18-1.74$ & 0.32 & 0.36 & $0.05-2.44$ & 0.30 \\
\hline Rectum & Reference & & & Reference & & \\
\hline \multicolumn{7}{|l|}{ Type of resection, \% } \\
\hline Ro & 0.03 & $0.01-0.07$ & $<0.001$ & 0.02 & $0.00-0.75$ & 0.034 \\
\hline $\mathrm{R} 1$ & 0.94 & $0.40-2.18$ & 0.88 & 0.51 & $0.07-3.52$ & 0.49 \\
\hline $\mathrm{R} 2$ & Reference & & & Reference & & \\
\hline Adjuvant chemotherapy & 6.24 & $1.89-20.62$ & 0.003 & 0.65 & $0.09-4.85$ & 0.67 \\
\hline Number of lymph nodes with metastasis*2 & 1.08 & $1.05-1.12$ & $<0.001$ & 1.13 & $1.04-1.23$ & 0.003 \\
\hline \multicolumn{7}{|c|}{$\begin{array}{l}\text { *1: Multivariate hazard ratios (HR), 95\% confidence intervals (CI), and } P \text { values were adjusted for age at diagnosis (years), gender, calendar month } \\
\text { of blood sampling, cancer stage (I, II, III, and IV), residual tumor after surgery (R0, no residual tumor; R1, microscopic residual tumor; R2, } \\
\text { macroscopic residual tumor), time period of surgery (between May } 2003 \text { and December } 2005 \text { or between January } 2006 \text { and January } 2008 \text { ), } \\
\text { location of tumor, adjuvant chemotherapy, and number of lymph nodes with metastasis. } \\
\text { *2: Lymph nodes were resected at surgery, and metastases in lymph nodes were confirmed pathologically. }\end{array}$} \\
\hline
\end{tabular}

because blood samples were taken only at the time of surgery and not at diagnosis; it is possible that samples taken at the time of diagnosis may have led to different results, because lifestyle factors, including outdoor activities and body mass index which are strongly associated with $25 \mathrm{OHD}$ levels might change in patients, when they are told they have colorectal cancer. However, because we did not include patients treated with chemotherapy and/or radiotherapy before surgery, we felt that changes in serum 25OHD levels from diagnosis to time of surgery would not be big. In addition, after surgery, 25OHD levels may change because of changes in physical activity, body mass index, and diet. However, because we only took blood samples at the time of surgery, we could not examine these potential effects. Moreover, we did not measure possible confounders such as physical activity and body mass index. In addition, because this was an observational study, treatment including adjuvant chemotherapy was not standardized, as it would have been in a clinical trial setting. Thus, the choice of therapy could also have an effect on the overall survival. Jikei University Hospital is a private hospital, and most patients were thought to live in Tokyo and the surrounding prefectures. Thus, our results could also have been confounded by socioeconomic factors. For example, patients living in Tokyo area may have higher opportunity to be diagnosed with colorectal cancer at an earlier stage because they are more likely to undergo screening tests or a medical check up, which can be associated with better survival. On the other hand, they may spend more time indoors, which could help explain why serum 25OHD levels were low. Recently, single nuclear polymorphisms of the vitamin D receptor were reported to strongly affect survival among patients with non-small-cell lung cancer [29]. Synergistic effects of single nuclear polymorphisms of vitamin D receptor and $25 \mathrm{OHD}$ on survival should be prospectively 
Table 5: Cox proportional hazard models of disease-free survival in patients with type of resection of R0 without or with multivariate adjustment*1

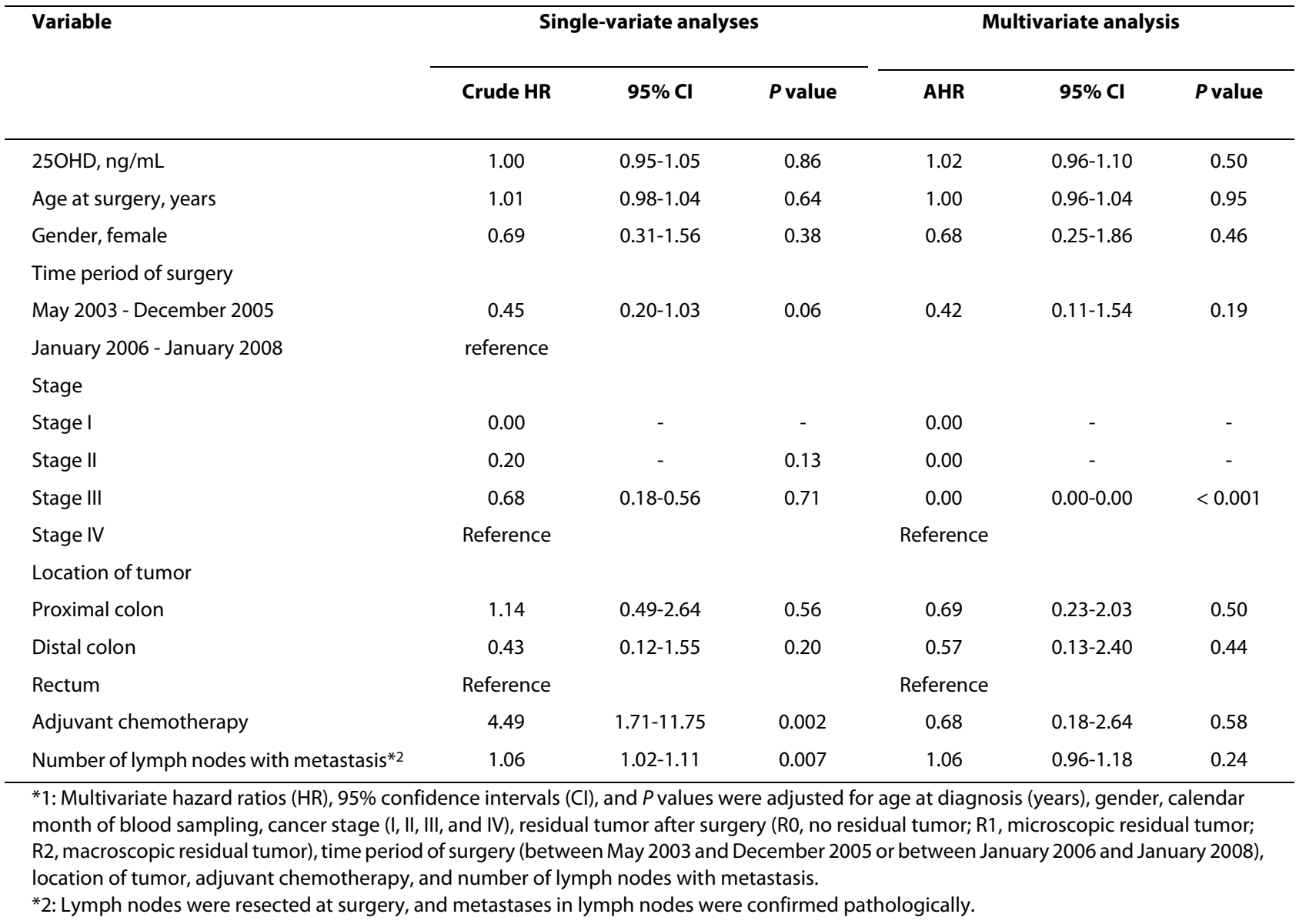

studied in the future. Moreover, clinical trials using high doses of vitamin D supplements are warranted to determine if vitamin D truly improves survival of patients with colorectal

cancer.

\section{Conclusions}

These results suggest that higher 25OHD levels at surgery may be associated with a better survival rate of patients with colorectal cancer.

\section{Competing interests}

The authors declare that they have no competing interests.

\section{Authors' contributions}

Substantial contributions to conception and design: TS, MW, MU Acquisition of data: HM, TS, MW, KY

Analysis and interpretation of data: HM, TS, CN, DT, AS, ST, YT, MU Drafting manuscript: HM, MU

Revising manuscript critically for important intellectual content: TS, MW

Final approval of the version to be published: All the authors

\section{Acknowledgements}

This work is supported by Jikei University grant.

\section{Author Details}

'Division of Molecular Epidemiology, Jikei University School of Medicine, Nishishimbashi, Minato-ku, Tokyo, Japan, 2Department of Paediatrics, Jikei University School of Medicine, Nishi-shimbashi, Minato-ku, Tokyo, Japan and ${ }^{3}$ Department of Surgery, Jikei University School of Medicine, Nishi-shimbashi, Minato-ku, Tokyo, Japan
Received: 17 September 2009 Accepted: 2 July 2010

Published: 2 July 2010

\section{References}

1. Peller S, Stephenson CS: Skin irritation and cancer in the United States Navy. Am J Med Sci 1937, 194:326-333.

2. Apperly FL: The relation of solar radiation to cancer mortality in North America. Cancer Res 1941, 1:191-195.

3. Garland CF, Garland FC: Do sunlight and vitamin D reduce the likelihood of colon cancer? Int J Epidemiol 1980, 9:227-231.

4. Holick MF: Vitamin D deficiency. N Engl J Med 2007, 357:266-281

5. Gorham ED, Garland CF, Garland FC, Grant WB, Mohr SB, Lipkin M, Newmark HL, Giovannucci E, Wei M, Holick MF: Optimal vitamin D status for colorectal cancer prevention: a quantitative meta analysis. Am J Prev Med 2007, 32:210-216.

6. Yin L, Grandi N, Raum E, Haug U, Arndt V, Brenner H: Meta-analysis: longitudinal studies of serum vitamin $\mathrm{D}$ and colorectal cancer risk. Aliment Pharmacol Ther 2009, 30:113-125.

7. Yang K, Kurihara N, Fan K, Newmark H, Rigas B, Bancroft L, Corner G, Livote E, Lesser M, Edelmann W, Velcich A, Lipkin M, Augenlicht L: Dietary induction of colonic tumors in a mouse model of sporadic colon cancer. Cancer Res 2008, 68:7803-7810.

8. Holt PR, Arber N, Halmos B, Forde K, Kissileff H, McGlynn KA, Moss SF, Kurihara N, Fan K, Yang K, Lipkin M: Colonic epithelial cell proliferation decreases with increasing levels of serum 25-hydroxy vitamin D. Cancer Epidemiol Biomarkers Prev 2002, 11:113-119.

9. Holt PR, Bresalier RS, Ma CK, Liu KF, Lipkin M, Byrd JC, Yang K: Calcium plus vitamin $D$ alters preneoplastic features of colorectal adenomas and rectal mucosa. Cancer 2006, 106:287-296.

10. Fedirko V, Bostick RM, Flanders WD, Long Q, Shaukat A, Rutherford RE, Daniel CR, Cohen V, Dash C: Effects of vitamin D and calcium supplementation on markers of apoptosis in normal colon mucosa: a 
randomized, double-blind, placebo-controlled clinical trial. Cancer Prev Res 2009, 2:213-223.

11. Lappe JM, Travers-Gustafson D, Davies KM, Recker RR, Heaney RP: Vitamin $D$ and calcium supplementation reduces cancer risk: results of a randomized trial. Am J Clin Nutr 2007, 85:1586-1591.

12. Wactawski-Wende J, Kotchen JM, Anderson GL, Assaf AR, Brunner RL, O'Sullivan MJ, Margolis KL, Ockene JK, Phillips L, Pottern L, Prentice RL, Robbins J, Rohan TE, Sarto GE, Sharma S, Stefanick ML, Van Horn L, Wallace RB, Whitlock E, Bassford T, Beresford SA, Black HR, Bonds DE, Brzyski RG, Caan B, Chlebowski RT, Cochrane B, Garland C, Gass M, Hays J, Heiss G, Hendrix SL, Howard BV, Hsia J, Hubbell FA, Jackson RD, Johnson KC, Judd H, Kooperberg CL, Kuller LH, LaCroix AZ, Lane DS, Langer RD, Lasser NL, Lewis CE, Limacher MC, Manson JE, Women's Health Initiative Investigators: Calcium plus vitamin D supplementation and the risk of colorectal cancer. N Engl J Med 2006, 354:684-696.

13. Ng K, Meyerhardt JA, Wu K, Feskanich D, Hollis BW, Giovannucci EL, Fuchs CS: Circulating 25-hydroxyvitamin d levels and survival in patients with colorectal cancer. J Clin Oncol 2008, 26:2984-2991.

14. Giovannucci E, Liu Y, Rimm EB, Hollis BW, Fuchs CS, Stampfer MJ, Willett WC: Prospective study of predictors of vitamin D status and cancer incidence and mortality in men. J Natl Cancer Inst 2006, 98:451-459.

15. Ng K, Wolpin BM, Meyerhardt JA, Wu K, Chan AT, Hollis BW, Giovannucci EL, Stampfer MJ, Willett WC, Fuchs CS: Prospective study of predictors of vitamin D status and survival in patients with colorectal cancer. $\mathrm{Br}$ 」 Cancer 2009, 101:916-923.

16. Greene FL, Balch CM, Fleming ID, Fritz A, Balch CM, Haller DG, Morrow M: AJCC Cancer Staging Handbook 6th edition. New York: Springer; 2002.

17. Mayer Robert J: Gastrointestinal tract cancer. Harrison's Principles of Internal Medicine Edited by: Fauci AS, Braunwald E, Kasper DL, Hauser SL, Longo DL, Jameson JL, Loscalzo J. Mc Graw Hill Medical; 1999:573-578.

18. Wittekind C, Compton CC, Greene FL, Sobin LH: TNM residual tumor classification revisited. Cancer 2002, 94:2511-2516.

19. Kobayashi T, Okano T, Shida S, Okada K, Suginohara T, Nakao H, Kuroda E, Kodama S, Matsuo T: Variation of 25-hydroxyvitamin D3 and 25hydroxyvitamin D2 levels in human plasma obtained from 758 Japanese healthy subjects. J Nutr Sci Vitamino/ 1983, 29:271-281.

20. Hollis BW, Kamerud JQ, Selvaag SR, Lorenz JD, Napoli JL: Determination of vitamin D status by radioimmunoassay with an 125 I-labeled tracer. Clin Chem 1993, 39:529-533.

21. Ginde AA, Liu MC, Camargo CA Jr: Demographic differences and trends of vitamin D insufficiency in the US population, 1988-2004. Arch Intern Med 2009, 169:626-632.

22. Hyppönen E, Power C: Hypovitaminosis D in British adults at age $45 \mathrm{y}$ : nationwide cohort study of dietary and lifestyle predictors. Am J Clin Nutr 2007, 85:860-868.

23. Moan J, Porojnicu A, Lagunova Z, Berg JP, Dahlback A: Colon cancer: prognosis for different latitudes, age groups and seasons in Norway. $J$ Photochem Photobiol B 2007, 89:148-155.

24. Autier P, Gandini S: Vitamin D supplementation and total mortality: a meta-analysis of randomized controlled trials. Arch Intern Med 2007, 167:1730-1737.

25. Artaza JN, Mehrotra R, Norris KC: Vitamin D and the cardiovascular system. Clin J Am Soc Nephrol 2009, 4:1515-1522.

26. Zhou W, Heist RS, Liu G, Asomaning K, Neuberg DS, Hollis BW, Wain JC, Lynch TJ, Giovannucci E, Su L, Christiani DC: Circulating 25hydroxyvitamin D levels predict survival in early-stage non-small-cell lung cancer patients. J Clin Oncol 2007, 25:479-485.

27. Goodwin PJ, Ennis M, Pritchard Kl, Koo J, Hood N: Prognostic effects of 25-hydroxyvitamin D levels in early breast cancer. J Clin Oncol 2009, 27:3757-3763

28. Freedman DM, Looker AC, Chang SC, Graubard BI: Prospective study of serum vitamin D and cancer mortality in the United States. J Nat Cancer Inst 2007, 99:1594-1602.

29. Heist RS, Zhou W, Wang Z, Liu G, Neuberg D, Su L, Asomaning K, Hollis BW, Lynch TJ, Wain JC, Giovannucci E, Christiani DC: Circulating 25hydroxyvitamin D, VDR polymorphisms, and survival in advanced nonsmall-cell lung cancer. J Clin Oncol 2008, 26:5596-5602.

Pre-publication history

The pre-publication history for this paper can be accessed here:

http://www.biomedcentral.com/1471-2407/10/347/prepub doi: 10.1186/1471-2407-10-347

Cite this article as: Mezawa et al., Serum vitamin D levels and survival of patients with colorectal cancer: Post-hoc analysis of a prospective cohort study BMC Cancer 2010, 10:347

\section{Submit your next manuscript to BioMed Central and take full advantage of:}

- Convenient online submission

- Thorough peer review

- No space constraints or color figure charges

- Immediate publication on acceptance

- Inclusion in PubMed, CAS, Scopus and Google Scholar

- Research which is freely available for redistribution

Submit your manuscript at www.biomedcentral.com/submit
C BioMed Central 